7. Лепкий Б. Вибрані твори : у 2 т.; упорядкув., вступ. сл. та передм. Н. Білик, Н. Гавдиди. Київ : Смолоскип, 2007-2011. T. 1.2007.604 c. T. 2.2011.614 c.

\section{REFRERENCES}

1. Bagriy, M.A. (2020). Pedahohichna ideyi i prosvitnytska diyalnist ukrayinskykh pysmennykiv Zakhidnoyi Ukrayiny (kinets XVIII 30-ti roky XX storichchya) [Pedagogical ideas and educational activities of Ukrainian writers of Western Ukraine (late XVIII 30-th years of the twentieth century): monograph]. (Ed.). G. Bilavich. Ivano-Frankivsk, 578 p. [in Ukrainian].

2. Vasyanovych, G. (2006). Pedahohichni ideyi Ivana Franka (prysvyachuyetsya 150-richchyu z dnya narodzhennya Kamenyara) [Pedagogical ideas of Ivan Franko (dedicated to the 150th anniversary of the birth of the Stonemason)]. Pedagogy and psychology of vocational education: Scientific and methodical journal. No. 3.pp. 117-128. [in Ukrainian].

3. Golubets, M. (1943). Zhyttyevyy shlyakh
B. Lepkoho. Bohdan Lepkyy, 1872-1941 : zb. u poshanu pamyati poeta [Life of B. Lepky. Bogdan Lepky, 18721941: coll. in honor of the poet]. Krakow; Lviv, 90 p. [in Ukrainian].

4. Zvidomlennya $\mathrm{z}$ diyalnosty Ukrayinskoho Pedahohichnoho Tovarystva za chas vid 1 veresnya 1922 do 31 serpnya 1923 [Report on the activities of the Ukrainian Pedagogical Society for the period from September 1, 1922 to August 31]. Lviv, 17 p. [in Ukrainian].

5. Ilyustrovanyy narodnyy kalyendar tovarystva "Prosvita" $\mathrm{z}$ teminarom na perestupnyy 1916. [Illustrated folk calendar of the society "Enlightenment" with a seminar on the criminal 1916]. (1915). Lviv, 190 p. [in Ukrainian].

6. Karmansky, P. (1936). Ukrayinska bohema : z nahody trydtsyatylittya Molodoyi Muzy. [Ukrainian bohemia: On the occasion of the thirtieth anniversary of the Young Muse]. Lviv. p. 43. [in Ukrainian].

7. Lepky, B. (2007, 2011). Vybrani tvory: u 2 t. [Selected works: in 2 volumes]. (Eds.). N. Bilyk, N. Gavdida. Kyiv, Vol. 1.604 p. Vol. 2.614 p. [in Ukrainian].

Стаття надійшла до редакції 04.02.2021

УДК 37:001.895

DOI:

Наталія Чубінська, кандидат педагогічних наук, асистент кафедри педагогіки та інноваційної освіти Інститут права, психологї̈ та інновачійної освіти Національного університету “Львівська політехніка"

\title{
ОСВІТА В УМОВАХ СЬОГОДЕННЯ: ВИКЛИКИ, РИЗИКИ, ПЕРСПЕКТИВИ
}

У статті зроблена спроба визначити цілі та завдання освіти в умовах інформатизачії, глобалізації, інтеграції суспільного простору. Визначено, що повноцінне функиіонування суспільства та освіти у ньому передбачає розширення рівня духовної, культурної, економічної, політичної та соціальної свободи особистості; розуміння рівня відповідальності людини за власне життєтворення; усвідомлення колективноі відповідальності за зміни як у суспільному співжитті, так і в природі тощо.

Ключові слова: освіта; суспільство; інформатизація; глобалізачія; інтеграція; суб'єкти освітньоі діяльності; зміст; сутність та специфіка інновацій.

Jim. 9.

Nataliia Chubinska, Ph.D.(Pedagogy), Assistant of the Pedagogy and Innovative Education Department, Institute of Law, Psychology and Innovative Education

Lviv Polytechnic National University

\section{EDUCATION IN THE NOWADAYS CONDITIONS: CHALLENGES, RISKS, PROSPECTS}

The author makes an attempt to define the purposes and tasks of education in the conditions of informatization, globalization, and integration of public space. It is determined that the full functioning of society and education in it involves the expansion of the level of spiritual, cultural, economic, political and social freedom of the individual; understanding the level of human responsibility for their own life; an awareness of collective responsibility for changes both in social coexistence and in nature, etc.

Modern scientists have identified the main determinants of the formation and development of the personalityoriented educational space, which consists in the progressive development of society in the direction of humanization of all social relations, recognition of freedom as one of the most important values of the individual; determined by the new social order, which in turn requires the effective training of qualified personnel for knowledge-intensive production, which uses new information technologies. It is important to take into account and overcome the contradictions between the mechanization, mechanization, informatization of society and the development of the spiritual world of the individual, for whom coexistence and communication with others is important.

An emphasis is placed on the priority of child-centeredness in the development of educational systems; on the 
preservation and development of pedagogical traditions and development of new pedagogical technologies; and on the maintaining of system of continuing education.

Thus, the modern social circumstances determined by the processes of informatization, globalization, integration, and technologicalization require the development and implementation of a new humanistic, democratic, child-centered, activity-oriented educational model. The social order requires the formation of a competent, free, responsible, creative, active, and capable of decision-making and adaptation to social change personality. Priority in these processes remains universal values, which only increase their potential weight in the technical and informative world.

Keywords: an education; a society; informatization; globalization; integration; subjects of educational activity; a content; the essence and specifics of innovation.

П остановка проблеми. Сучасний світ перебуває у стані глобальних змін і трансформацій, які накладають відбиток на усі сфери суспільного життя, зокрема на освіту. На початку XXI ст. процеси реформування системи освіти відображені у низці нормативних документів, зокрема: "Національна стратегія розвитку освіти в Україні на період до 2021 року" (2013), концепція "Нова українська школа” (2016), Закон України “Про освіту” (2017), де системно і науково представлено стратегію розвитку освіти крізь призму стрімкого суспільного розвитку.

В Україні на законодавчому рівні задекларовано, що метою державної політики у сфері освіти $€$ турбота про розвиток і становлення самобутньої особистості з урахуванням їі прагнень, інтересів, талантів, здібностей тощо: “Метою освіти $є$ всебічний розвиток людини як особистості та найвищої цінності суспільства, її талантів, інтелектуальних, творчих і фізичних здібностей, формування цінностей і необхідних для успішної самореалізації компетентностей, виховання відповідальних громадян, які здатні до свідомого суспільного вибору та спрямування своєї діяльності на користь іншим людям і суспільству, збагачення на цій основі інтелектуального, економічного, творчого, культурного потенціалу Українського народу, підвищення освітнього рівня громадян задля забезпечення сталого розвитку України та її європейського вибору" [6].

Отже, інноваційність і пріоритетне завдання сучасної освіти полягає, з одного боку, в урахуванні стану сучасного суспільства в умовах інформатизації, глобалізації, інтеграції, а з іншого - у врахуванні потреб кожної окремої людини 3 раннього віку на всіх етапах її життя. Мова також іде про те, що слід сприяти вихованню покоління людей, здатних ефективно працювати і навчатися протягом життя, оскільки сьогоднішні знання та уміння уже завтра можуть бути не актуальними.

Аналіз останніх досліджень і публікацій. Такі обставини суспільного життя у його глобальному вимірі ставлять перед педагогічною, філософською та психологічною науками завдання розробки науково обгрунтованого педагогічного інструментарію забезпечення такого підходу до освіти особистості, який допоможе кожному стати свідомим та

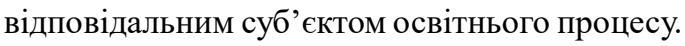

Означені проблеми стали предметом обсервації представників освітньої галузі і спонукали учених до пошуку таких парадигм і технологій освіти, які б могли забезпечити окремій особистості і суспільству загалом прогресивний поступ і продуктивний розвиток:

- питання приєднання української освіти до європейського простору в умовах суспільних трансформацій висвітлені в доробку В. Андрущенка “Організоване суспільство. Проблеми організації та суспільної самоорганізації в період радикальних трансформацій в Україні на рубежі століть: досвід соціально-філософського аналізу” [1];

- проблема розробки стратегій задля удосконалення системи освіти на всіх іiі рівнях дослідження упраці В. Журавського, М. Згуровського "Болонський процес: головні принципи входження в Свропейський простір вищої освіти” [5];

- інноваційність і суперечливість освітніх процесів в Україні та світі відображено у студії С. Ніколаєнка “Стратегія розвитку освіти України: початок XXI ст.” [8];

- шляхи і способи реалізації інновацій в освіті проаналізовано у роботі.

В. Кременя “Освіта і наука України: шляхи модернізації” [7] тощо.

Мета статті полягає у вивченні й узагальненні змісту, сутності та специфіки змісту освіти 3 огляду на суспільні детермінанти в умовах сьогодення.

Виклад основного матеріалу. Стан i механізми становлення сучасного суспільства свідчать про те, що вектори його розвитку можуть бути діаметрально протилежними i потребують усвідомлення і розуміння усіх викликів та ризиків, що пов'язані 3 інформатизацією, технологізацію, інтеграцією тощо. Сьогодні питання про роль людини у суспільстві, мету людського життя і визначення оптимальних шляхів удосконалення суспільного організму стають особливо значимими i важливими. Вчені вважають, що найбільш 
важливим критерієм прогресу людства є рівень гуманізації суспільства: "Ми живемо в часи не просто хронологічної зміни епох, а й динамічної зміни структури і якості людської цивілізації. Визначальними у цих змінах є процеси децентралізації, інформатизації, демократизації, індивідуалізації. В один ряд 3 ними можна поставити і процес гуманізації суспільства, котрий, як цивілізаційний виклик початку XXI ст., означає “небувале досі зближення матеріального і духовного рушіїв людського буття" $[4,183]$.

Повноцінне функціонування суспільства та освіти у ньому передбачає:

- розширення рівня духовної, культурної, економічної, політичної та соціальної свободи особистості;

- піднесення рівня задоволення духовних i матеріальних потреб людини;

- турботу про фізичне, психічне та соціальне здоров'я кожного;

- усвідомлення колективної відповідальності за зміни як у суспільному співжитті, так і в природі;

- розуміння рівня відповідальності за власне життєтворення;

- розуміння пролонгованості наявних проблем і відповідальність перед наступними поколіннями за їх продуктивне і позитивне розв'язання тощо.

Освіта у цьому сенсі має чи не всі важелі, щоб сприяти творенню такої людини, яка б усвідомлювала відповідальність за себе та своїх потомків. Посилюються вимоги до людини, яка сама повинна турбуватися і по себе, і про тих, хто їі оточує, і про тих, хто буде жити через століття чи тисячоліття. У зв'язку з цим справедливо зазначає канадський дослідник Майкл Фуллан: “громадяни як індивідуально, так i колективно у контексті динамічних багатокультурних, глобальних змін повинні бути здатними впродовж усього життя здійснювати зміни, а не реагувати на них" [9, 22-23].

Констатуємо неспроможність сучасної освіти сприяти становленню такої особистості, яка легко і просто пристосовується до викликів сучасного життя і вміло протистоїть тим проблемам, які загострюються i набирають характеру глобальних світових проблем (екологічна ситуація, соціальні потрясіння, міграційні процеси, економічна криза, демографічні проблеми тощо). Це, очевидно, є свідченням необхідності кардинальних освітніх реформ.

Представники провідних європейських університетів, обгрунтовуючи завдання спільного освітнього простору та його ефективності в умовах сьогодення, вважають, що:
- “майбутнє людства на сьогодні залежить значною мірою від культурного, наукового і технічного розвитку, який формується в центрах культури, знань і досліджень, які стали справжніми університетами;

- поширення новітніх знань вимагає на сьогодні, щоб вони ставали надбанням всього суспільства в цілому;

- університет повинен забезпечити майбутнім поколінням таку освіту і таку підготовку, які дозволять їм зробити свій внесок у дотримання великої рівноваги навколишнього середовища i самого життя" [2].

3 огляду на це нова освіта повинна закласти основи розуміння такого світопорядку, що постійно змінюється, перебуває у динаміці. Такі ж вимоги ставляться і до особистості, яка у ньому проживає, - людина повинна перебувати у стані постійного творення себе і світу навколо себе.

Пріоритети особистісного розвитку вбачаються вченими у посиленні суб' єктності особистості, що полягає в ії активності, креативності, діяльності, відповідальності, свободі: “Нові умови життя передбачають таке виховання, котре забезпечувало б формування у характері розкутої людини механізмів самоконтролю, самокорекції, самообмеження, самоорієнтації - не під впливом страху, а на основі власного погляду на життя, особистої волі та розуму, власної віри. Але це можливе лише в тому разі, якщо її виховання буде здійснюватися 3 самого початку в умовах свободи - в сім’ї і в школі” [3].

Сучасними науковцями визначені головні детермінанти становлення і розвитку особистісно орієнтованого освітнього простору $[1 ; 3 ; 4 ; 5 ; 7 ; 8]$ :

- прогресивний розвиток суспільства у напрямкі гуманізації усіх суспільних відносин, визнання свободи як однієї із найважливіших цінностей особистості;

- нове соціальне замовлення вимагає ефективної підготовки висококваліфікованих кадрів для обслуговування нового наукомісткого виробництва, яке послуговується новими інформаційними технологіями;

- важливим є урахування та подолання суперечності між технізацією, механізацією, інформатизацією суспільства і розвитком духовного світу особистості, для якої важливим $є$ співжиття та спілкування з іншими;

- зростає цінність духовного світу людини, коли важливими і необхідними елементами ії життя стають мораль, право, мистецтво, наука тощо;

- гуманізуватися повинно також соціальне управління, сутність якого зводиться до розуміння мети освіти як соціального інституту і координації 
зусиль усіх суспільних згромаджень задля досягнення мети освіти - побудови особистісно оріснтованої її моделі;

- пріоритет дитиноцентризму у розвитку освітніх систем; збереження й розвиток педагогічних традицій i розвиток нових педагогічних технологій; збереження системи безперервної освіти.

Висновки. Отже, сучасні суспільні обставини детерміновані процесами інформатизації, глобалізації, інтеграції, технологізації вимагають розробки і впровадження нової гуманістичної, демократичної, дитиноцентричної, діяльнісно орієнтованої освітньої моделі. Соціальне замовлення вимагає становлення людини компетентної, вільної, відповідальної, творчої, активної, здатної до прийняття рішень і пристосування до суспільних змін. Пріоритетними у цих процесах залишаються загальнолюдські цінності, які лише посилюють свою потенційну вагу у технізованому чи інформатизованому світі.

\section{ЛІТЕРАТУРА}

1. Андрущенко В.П. Організоване суспільство. Проблеми організації та суспільної самоорганізації в період радикальних трансформацій в Україні на рубежі століть: досвід соціально-філософського аналізу. Київ: ТОВ “Атлант ЮЕмСі”, 2005. 498 с.

2. Болонський процес: нормативно-правові документи / уклад. 3.І. Тимошенко. Київ: Вид-во Європейського ун-ту, 2004. 168 с.

3. Вишневський О.І. Теоретичні основи сучасної української педагогіки. Посібник для студентів вищих навчальних закладів. Дрогобич: Коло, 2006. $608 \mathrm{c}$.

4. Горбатенко В.П. Стратегія модернізації суспільства: Україна і світ на зламі тисячоліть. Київ: Видавничий центр “Академія”, 1999. С. 183.

5. Журавський, В.С. Болонський процес: головні принципи входження в Свропейський простір вищої освіти. / В.С. Журавський, М.3. Згуровський. Київ: ІВЦ. Видавництво "Політехніка", 2003. 200 с.

6. Закон України “Про освіту”. URL: http:// ru.osvita.ua/legislation/law/2231/

7. Кремень В.Г. Освіта і наука в Україні інноваційні аспекти. Київ: Грамота. 2005. 446 с.

8. Ніколаєнко С.М. Стратегія розвитку освіти
України: початок XXI століття. Київ: Знання, 2006. $253 \mathrm{c}$.

9. Фуллан М. Сили змін: Вимірювання глибини освітніх реформ. Львів: Літопис, 2000. С. 22-23.

\section{REFERENCES}

1. Andrushchenko, V.P. (2005). Orhanizovane suspilstvo. Problemy orhanizatsii ta suspilnoi samoorhanizatsii v period radykalnykh transformatsii v Ukraini na rubezhi stolit: dosvid sotsialnofilosofskoho analizu [An organized society. The problems of organization and social self-organization in the period of radical transformations in Ukraine at the turn of the century: the experience of sociophilosophical analysis]. Kyiv, 498 p. [in Ukrainian].

2. Bolonskyi protses: normatyvno-pravovi dokumenty (2004). (Ed.). Tymoshenko Z.I. [Bologna process: legal documents]. Kyiv, 168 p. [in Ukrainian].

3. Vyshnevskyi, O.I. (2006). Teoretychni osnovy suchasnoi ukrainskoi pedahohiky [The theoretical foundations of modern Ukrainian pedagogy]. Handbook for students of higher educational institutions. Drohobych, 608 p. [in Ukrainian].

4. Horbatenko, V.P. (1999). Stratehiia modernizatsii suspilstva: Ukraina i svit na zlami tysiacholit [Strategy for modernization of society: Ukraine and the world at the turn of the millennium]. Kyiv, p. 183. [in Ukrainian].

5. Zhuravskyi, V.S. \& Zghurovskyi, M.Z. (2003). Bolonskyi protses: holovni pryntsypy vkhodzhennia v Yevropeiskyi prostir vyshchoi osvity [The Bologna Process: the main principles of entering the European Higher Education Area]. Kyiv, 200 p. [in Ukrainian].

6. Zakon Ukrainy "Pro osvitu" [Law of Ukraine "On Education"]. Available at: http://ru.osvita.ua/ legislation/law/2231/ [in Ukrainian].

7. Kremen, V.H. (2005). Osvita i nauka v Ukraini - innovatsiini aspekty [Education and science in Ukraine - innovative aspects]. Kyiv, 446 p. [in Ukrainian].

8. Nikolaienko, S.M. (2006). Stratehiia rozvytku osvity Ukrainy: pochatok XXI stolittia [Strategy of development of education of Ukraine: the beginning of the XXI century]. Kyiv, 253 p. [in Ukrainian].

9. Fullan, M. (2000). Syly zmin: vymiriuvannia hlybyny osvitnikh reform [Forces of change: Measuring the depth of educational reforms]. Lviv, pp. 22-23. [in Ukrainian].

Стаття надійшла до редакції 04.02.2021

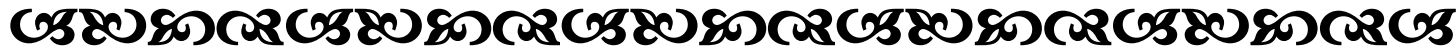

"Трагнення до нового - периа потреба людсьқоі уяви".

Стендаль браниузький письменник

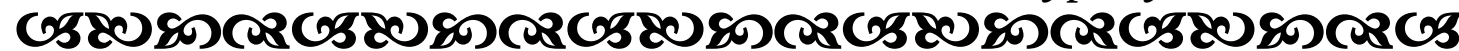

